\title{
Bullous diffuse cutaneous mastocytosis
}

INSERM

\section{Source}

INSERM. (1999). Orphanet: an online rare disease and orphan drug data base. Bullous diffuse cutaneous mastocytosis. ORPHA:280785

Bullous diffuse cutaneous mastocytosis (BDCM) is a form of diffuse cutaneous mastocytosis (DCM; see this term) characterized by generalized erythroderma and severe blistering associated with the accumulation of mast cells in the skin. 